\title{
Students' perceptions on the effectiveness of Modified GI in the reading comprehension achievement
}

\author{
Achmad Alfarezi ${ }^{1}$, Feni Munifatullah ${ }^{2}$, Tuntun Sinaga ${ }^{3}$ \\ \{achmadalfarezi@gmail.com ${ }^{1}$, feni.munifatullah@fkip.unila.ac.id ${ }^{2}$, tuntunsinaga@fkip.unila.ac.id ${ }^{3}$ \} \\ First Author, Lampung University ${ }^{1}$, Coresponding Author, Lampung University ${ }^{2}$ Third Author, \\ Lampung University ${ }^{3}$
}

\begin{abstract}
This present study was aimed to examine the student's perception in relation with the modified group investigation (GI) effectiveness in teaching reading comprehension for junior high schools' students in Indonesia. The data were collected from the students at the 8th grade of SMPN (junior high school) in Bandar Lampung by administering a questionnaire on the students' perception. The results of the questionnaire show that the students got a positive perception on the effectiveness of modified group investigation. Specifically, the data show that the modified GI enables students to a better understanding of the material, facilitates the students to express their ideas freely and promotes the students' active learning process and collaborative work in group.
\end{abstract}

Keywords: student's perception, teaching reading comprehension, modified GI

\section{Introduction}

Students are the centre of the learning process. They have to experience the engagement in learning in order to develop them into an educated person. Learning English for students is quite challenging because they have to be exposed to the language intensively while they develop the ability to learn together. Teachers have to assure that the students learn in a supportive situation in the process of learning English.

Reading is the means of finding the pupose of expressions and words in the pessage[1]. Reading is an understanding of the text or written language or symbol that required by society and/or valued by the individual [2]. In addition, reading is a way of recognation and comprehending text as a skill [1]. Therefore, reading is an activity of discovering the meaning of the passage. In addition, reading comprehension refers to the getting and finding ideas in the text before, during, and after reading by combining the various statements written by the author with the reader's prior knowledge. Furthermore, reading is a way of merging the various sources to get good understanding [3].

As language learners, the learners should be able to extract and get the meaning from the reading text. But in fact, in several countries in Asia in which English taught as a foreign language, most of the students need a lot of time and get difficulties to comprehend the reading text. According to Nezami who classified reading problem in the classroom activity into four aspects 1 Vocabulary aspect as a tool for reading activity 2 Difficulty in Skimming and Scanning process of Reading 3 Problems appears during Prediction of Passage with readers' background Knowledge 4 Incompentece in the Skill of Summarizing of reading text [4]. 
Regarding those problems, GI can be the solution for students' reading comprehension problems in selecting and designing reading comprehension activity. GI focuses on group work and it has a communicative method for teaching and learning activity in which students perform in group interaction to exchange the information. It is a method for classroom activity in which pupils perform through peer interaction to examine, impression, and comprehend the discussion topic in learning process. The students do the task together through group interaction to achieve the learning outcome. Hence, it will assist the learner in reaching reading comprehension achievement more completely [5].

As a matter of fact, CL is a learning strategy that is systematically structured and it can be used at all grade levels in school and campus [6]. The cooperative situation during groups activity and the cooperation shown by students provides opportunities to improve student comprehension [7]. Those statements are in line with several previous study, studies have signified that CL as a learnung strategy turns out to be a valuable method to support students learn reading comprehension skill while encouraging positive attitudes among group members [8].

Many studies have been conducted on the effect of using cooperative learning methods for students' perception and reading achievement. Some studies concentrate on conducting their research to compare the effectiveness of various cooperative learning methods. For example, the examination of student team achievement division (STAD) and group investigation (GI) techniques on students' reading comprehension achievement of English as a Foreign Language (EFL) [9],[8]. There are also studies that observe the effect of group investigation on achievement, motivation, and perceptions of students in Singapore [10] or on the specific language skill achievement like writing [11]. More studies in different subject matter recommend the effect of GI methods in improving the critical thinking skills [12] or basic knowledge and skills [13], or students' achievement and retention [14].

However, the study of students' perception when the teacher uses modified GI to improve reading comprehension achievement is a dimension that researchers need to explore. As a matter of fact, students' perception is needed to listen to students' response. This study examines students' perception to the implementation of modified GI in reading comprehension in an English class as a Foreign Language (EFL) of eighth-grade students in SMP in Bandar Lampung. It specifically focuses on the effectiveness of implementing modified GI; that is, asking questions about the parts of the advantages of using modified GI.

\section{Literature Review}

\subsection{Students' Perception}

Perception is the way the senses being aware of many stimuli [15]. The students' perception refers to perceiving their EFL learning experience learning goal and/or learning activity provided by the teacher [16]. In line with this statement, there is a finding of a study that reveals that students' perception is related to the students' perceiving of the learning goal. It means that students' perceptions are related to the effect of implementing a method in the teaching and learning process [17] and the perceptions of students and/or teachers are seen to be important in controling the process of applying method or technique in courses [18]. It can be concluded that 
to know the effectiveness of applying a method or technique in the learning activity, the students' perception is needed to be explored by the teacher.

\subsection{Reading Comprehension}

Reading comprehension is the activity of comprehending and exctracting the meaning or information from in the text. The process of comprehension take place when the reader issues and merges various understading and combines it with the prior knowledge and information they already knew. It means that comprehension is the process of integrating the information of an activity, and the comprehension process also include the activity of combining the prior knowledge and the new information to construct the meaning from the text. Thus, the whole comprehension procedure is a vital point for the reader in the reading process [19].

In brief, reading comprehension is defined as an activity to comprehend the symbol or printed word in the form of text including extracting the various information in the text. In the comprehension process, the interaction between reader background knowledge and new information contained in the text occurs to achieve the optimum level of accepting the ideas expressed in the text. Hence, the reader can construct meaning and get new information through this process [7].

\subsection{Modified GI Learning Strategy}

CL is derived from the word cooperative which means solving problems together by supporting each other as a peers. There has been a belief that cooperative learning is one of the important learning strategies for students working together in getting common goals. The CL strategy provides the peer cooperation and interdependence in its projects, learning objective, and honor [20]. Cooperative learning defined as "students work together in a small cooperative group to investigate the learning material" [21],[8]. Cooperative learning emphasizes understudy cooperation as opposed to learning as an individual that works in a group to solve the problem and find the solution [22].

GI is a multiplex strategy in the cooperative learning strategy. But this statement also implies that it is the most organized strategy in cooperative learning [6]. The goal of group investigation is to make member of group conduct the investigation as a peer interaction and formulate the final project at the end of the learning process. GI provides students to group discussion, make a learning plan and conduct the investigation acticty, integrate the final project, and present their final project in the class [10]. from the detailed structure of the GI strategy, GI makes sure that every member of group has judgment (such as ideas and opinions) to supply their role in group interaction by giving students the freedom during the classroom activity. In addition, it makes students work and think actively while they have the opportunity to assist the team. Hence, all the member of group has something to join the investigation.

The result of the analysis also suggests that group investigation is a strategy in the form of student team's plan for classroom instruction in which they make sure the students choose the topics to be discussed and how to conduct their group plan. Thus, GI is a learning strategy that organizes the learners into groups interaction that make students work as a team collaboratively and help each other. 
Regarding the clarifications above, it can be assumed that GI is a comprehensive strategy in cooperative learning that can make the students assist each other to understand the material by discussing the text in a group. This strategy makes students work together with their friends to solve their problems as a group work.

\section{Research Methodology}

This is a decriptive quantitative research. Its setting is in Bandarlampung. The sample is the students of junior high school in the second grade. The instrument is a 4-scal, close-ended questionairre validated and tried out before being adiministered.

\subsection{Population and Sample}

The population of this research is the students of the eighth grades of in the school where the GI was implemented in the 2019/2020 academic years. The population of this research is three classes of second graders. The number of students of each class is around 29 to 30 students. By using cluster random sampling, the cluster was preferred as the sample of this study. The class learned the English reading comprehension for understanding the recount texts through the modified GI model.

\subsection{Data Collection Procedure}

Two questionnaires were distributed (before and after the implementation), The first questionnaire contains of 10 items that are related to the pupils experience in the teaching and learning process as a group. This questionnaire has been validated by three validators to confirm the validity of each item in the questionnaire.

The second questionnaire consists of 4 items which cover the effectiveness of using modified GI. The items of the questionnaire are adopted from WL [15]. This instrument aims at finding out students' perception after being taught by using modified GI. This questionnaire is related to the students' perceptions of effectiveness of using modified GI in teaching reading comprehension. The questionnaire includes four-scale scoring system to indicate the positive or negative perception.

As the pandemic condition does not allow the students to meet and learn in the real classroom, the second questionnaire were distributed online through Google Form to get the data from the students after the implementation, the questionnaire responses were then collected and organized. 


\subsection{Data Analysis}

Following the design of the research as a descriptive quantitative research, the data of the questionnaire responses are scored and calculated to get the trends of the response; whether it is a positive trend or the negative one.

\section{Result and Discussion}

The students' perception before experiencing the GI is presented in Table 1.

Table 1. Students' Perception before Giving the Treatment

\begin{tabular}{|c|c|c|c|}
\hline \multirow{2}{*}{ No. } & \multirow{2}{*}{ Statement } & \multicolumn{2}{|c|}{ Option } \\
\hline & & Yes & No \\
\hline 1. & Have you ever heard or seen the term "group investigation"? & $22.2 \%$ & $77.8 \%$ \\
\hline 2. & $\begin{array}{l}\text { Have you ever learned English reading skills by sitting in a } \\
\text { group? }\end{array}$ & $83.3 \%$ & $16.7 \%$ \\
\hline 3. & $\begin{array}{l}\text { Have you ever learned English reading skills by performing a } \\
\text { discussion? }\end{array}$ & $72.2 \%$ & $27.8 \%$ \\
\hline 4. & $\begin{array}{l}\text { Have you ever learned reading skills in English by } \\
\text { investigating a specific material? }\end{array}$ & $72.2 \%$ & $27.8 \%$ \\
\hline 5. & $\begin{array}{l}\text { Have you ever learned reading a text in English by gathering } \\
\text { information with a number of group members? }\end{array}$ & $61.1 \%$ & $38.9 \%$ \\
\hline 6. & $\begin{array}{l}\text { Have you ever experienced learning English by using learning } \\
\text { task plan? }\end{array}$ & $16.7 \%$ & $83.3 \%$ \\
\hline 7. & Have you ever known learning by using final project? & $44.4 \%$ & $55.6 \%$ \\
\hline 8. & $\begin{array}{l}\text { Have you ever presented your final project in front of the } \\
\text { class? }\end{array}$ & $66.7 \%$ & $33.3 \%$ \\
\hline 9. & $\begin{array}{l}\text { Has your friend ever given you a written feedback while you } \\
\text { are studying? }\end{array}$ & $83.3 \%$ & $16.7 \%$ \\
\hline 10. & $\begin{array}{l}\text { Has your friend ever given an oral feedback while you are } \\
\text { studying? }\end{array}$ & $77.8 \%$ & $22.2 \%$ \\
\hline
\end{tabular}

From the data in the figure, it is shown that $77 \%$ students responded by stating that they never heard the term of group investigation. On the contrary, when the students were asked detailly for each activity in GI, 49,4\% students has experienced them. Meanwhile, $83.3 \%$ of the students ever learned reading comprehension by performing a discussion. Therefore, it is evident that group learning discussion was known as cooperative learning, and a specific term known as GI is not familiar to the students, yet. 
4.1 Students' perception concerning the modified group investigation effectiveness in teaching reading comprehension.

Table 2. Students' perception related to the use of MGI

\begin{tabular}{|c|c|c|c|c|c|}
\hline \multirow{2}{*}{ No. } & \multirow{2}{*}{ Statement } & \multicolumn{4}{|c|}{ Option } \\
\hline & & Strongly Agree & Agree & Disagree & Strongly Disagree \\
\hline 1. & $\begin{array}{l}\text { Modified group } \\
\text { investigation strategy is } \\
\text { useful. }\end{array}$ & $33.3 \%$ & $66.7 \%$ & $0 \%$ & $0 \%$ \\
\hline
\end{tabular}

Table 3. Students' perception related to the effectiveness of MGI

\begin{tabular}{|c|c|c|c|c|c|}
\hline \multirow[b]{2}{*}{ No. } & \multirow[b]{2}{*}{ Statement } & \multicolumn{4}{|c|}{ Option } \\
\hline & & $\begin{array}{c}\text { Strongly } \\
\text { Agree }\end{array}$ & Agree & Disagree & $\begin{array}{l}\text { Strongly } \\
\text { Disagree }\end{array}$ \\
\hline 2. & $\begin{array}{l}\text { Learning reading } \\
\text { comprehension using } \\
\text { Modified group investigation } \\
\text { strategy is effective. }\end{array}$ & $33.3 \%$ & $66.7 \%$ & $0 \%$ & $0 \%$ \\
\hline
\end{tabular}

As shown in Table 2 and Table 3, all of the students agreed with the first question. From this response, it seems that $100 \%$ students had good perception in participating in GI activities during the reading comprehension class. Furthermore, it revealed $100 \%$ of students in experimental class agreed with the statement about the effectiveness of modified GI strategy. It could be concluded that the students give a positive perception about the effectiveness in the implementation of modified GI, the students believed that using modified GI in reading comprehension class is effective.

Table 4. Students' perception related to the advantages of MGI

\begin{tabular}{|c|c|c|c|c|c|}
\hline \multirow[b]{2}{*}{ No. } & \multirow[b]{2}{*}{ Statement } & \multicolumn{4}{|c|}{ Option } \\
\hline & & $\begin{array}{c}\text { Strongly } \\
\text { Agree }\end{array}$ & Agree & Disagree & $\begin{array}{l}\text { Strongly } \\
\text { Disagree }\end{array}$ \\
\hline 3. & $\begin{array}{l}\text { I get many advantages } \\
\text { while learning reading } \\
\text { comprehension using } \\
\text { Modified group } \\
\text { investigation strategy. }\end{array}$ & $40 \%$ & $60 \%$ & $0 \%$ & $0 \%$ \\
\hline
\end{tabular}

As presented in Table 4, 100\% of the students agreed on item number 3, by indicating that they had an interactive class and the students could exchange ideas as collaborative work in group interaction. In addition, the students could engage in pair work and group discussion and they could establish class spirit. 
Table 5. Students' perception related to the disadvantages of MGI

\begin{tabular}{|c|c|c|c|c|c|}
\hline \multirow[b]{2}{*}{ No. } & \multirow[b]{2}{*}{ Statement } & \multicolumn{4}{|c|}{ Option } \\
\hline & & $\begin{array}{c}\text { Strongly } \\
\text { Agree }\end{array}$ & Agree & Disagree & $\begin{array}{l}\text { Strongly } \\
\text { Disagree }\end{array}$ \\
\hline 4. & $\begin{array}{l}\text { I get many disadvantages } \\
\text { while learning reading } \\
\text { comprehension using the } \\
\text { Modified group } \\
\text { investigation strategy. }\end{array}$ & $13.3 \%$ & $13.3 \%$ & $66.7 \%$ & $6.7 \%$ \\
\hline
\end{tabular}

As presented in table 5, students' response in the fourth part of the questionnaire indicated that students generally had good perception on the item. There were $26.6 \%$ students who gave negative perceptions. However, $73.4 \%$ students give positive perceptions. It can be inferred that most students did not get disadvantages in implementing modified GI while there were some students who felt modified GI gave them some disadvantages during the implementation. It seems that students did not get the chance to share their ideas in peer interaction or group interaction, the students hesitate to communicate via whatsapp group.

The result shows the students' perceptions toward the effectiveness of modified GI (Question number 1 and 2). Besides, students' perception toward the advantages of Modified GI is $73,4 \%$ disagree on the disadvantages of the modified GI strategy. So, it can be concluded that the students have thought that modified GI in reading comprehension is advantageous for learning. Modified GI provides many advantages for reading comprehension activities like they had more interaction in group activity to exchange the idea from each group. The advantages for the students are as follows: (1) Motivate students to learn, (2) Gain confidence while learning as a result of peer support, (3) Improve student achievement [6].

Based on the data above, the positive result of students' perception level in reading comprehension class was confirmed. The data shows that most of the students during the implementation were in good condition of each perception aspect. This means that most students feel satisfied with the implementation. Moreover, based on the questionnaire result, it could be inferred that most students felt free to make some statements without any limitation. In addition, the students show fluency in communicating with their friends during the peer interaction.

The study also indicates that the students' perceptions show a satisfactory trends towards the course when the students are working with the activities of modified GI in reading comprehension class. The study indicates that the group activities which includes the investigating process reflect a positive activities and product of the students. The implementation of modified GI in the group discussion framework provides students with freedom over their learning and generated in them a high sense of responsibility which made their learning a meaningful activity.

The result of students' perception implies that using Modified GI is effective, gives students a chance to express their ideas freely, and make students active in the classroom activity. It means that by using modified GI in reading comprehension class, the students keep the focus on the lesson and the activities trigger the students to keep learning while they could make group interaction. It coupled with the aim of group work is to trigger and give the facilities among peers to be active in the investigation process. Similar findings have been shown in Marzban \& Alinejad [20].

Moreover, during the investigation session, most of the students were enthusiastic to join the activity. Besides, students were confident in delivering the ideas through the investigation. 
In line with the result above, Ahsanah confirmed in her study that GI is gainful for the students because it can solve their weakness in English skill [5]. One of the weaknesses which often appear is the lack of confidence. The lack of confidence makes the students scared to share their ideas in discussion. During the implementation of the modified GI, students are active and enjoy the discussion activity.

In addition, the study is also relevant to jalilifar [8] because the students help each other as group member to interpret and manage the written language accurately in a text. It triggers the students to be active in reading comprehension activity. Similarly, this study also supports Karafkan [7] because students in the investigation group get help and support from competent peers in the group. Student contributions are valued in the group to achieve learning goals. GI provides an activity for peers to help each other to answer a question or comprehend a text.

Most students assumed that modified GI authorizes their activity in finding information through group intercation. Furthermore, they agree if interaction can improve English more than just learning from teachers and helps everyone reach the goal equally. Overall, the results show that the students get positive results in applying modified GI in reading comprehension classroom.

Furthermore, the students' perception stated that using modified group investigation is effective, gives students a chance to express their ideas freely, and makes students active in the classroom activity. It means that by using modified group investigation in reading comprehension class, make the students keep focus on the lesson and trigger the students to keep learning while they could make group interaction. It coupled with the aim of group work is to trigger and give opportunity to the students to be active in the learning process.

Hence, there is a trend that the implementation of presentation as the teaching learning activity influences students' reading comprehension achievement. This situation is also reported by Parinduri et al., they claimed that the implementation of cooperative learning model GI as a teaching procedure improves student' achievement [13].

In conclusion, students' positive perception is in line with the students' reading comprehension achievement. Modified GI can help the students learn reading comprehension. The use of group discussion may support the learning or receptive reading comprehension. Based on data of the questionnaire showed that students' perception toward reading comprehension class using modified GI, through these questionnaires we can explain that: Most of the students like learning reading comprehension using modified GI because it triggers them to be active while learning in the reading comprehension activity and it gives more input and opportunity to the students without limitation to create the active situation while the investigation and the peer interaction.

In addition, it is important to note that the significant comparison between a simple discussion and GI is that GI is enforced by the emphasis to the investigation activity. Yet, many teachers implement most of the activities of GI but skipped the investigation process. In other words, there is a possibility that teachers may have insufficient knowledge about the strategies, both the cooperative learning, in general, and GI, specifically. It is suggested that teachers could study the procedures in any cooperative laerning strategies theoretically and practically in order to get the maximum result of the activities. 


\section{Conclusion}

Based on the data from the questionnaire, modified GI helps students in the process of constructing meaning and getting information. Almost all students thought that modified GI assists them to acquire the information through investigation activity and it provides the active learning process. Moreover, students assumed that during the implementation they could learn reading comprehension not only by the teacher but they could learn by making group discussion or group interaction to gather information. Based on the result of students' perception, modified GI produces good stimulus for the students to achieve the learning objective by helping each other as group work. In short, modified GI is one of the successful methods to carry out in reading comprehension class.

\section{References}

[1] Patel, M. and Jain, P. M. 2008. English Language Teaching. Jaipur: Sunrise Publisher.

[2] Støle, H., Mangen, A., and Schwippert, K. Assessing children's reading comprehension on paper and screen: A mode-effect study. Elsevier. vol. 151, no. 103861, pp. 1-13, 2020.

[3] Namaziandost, E., Gilakjani, A. P., and Hidayatullah. 2020. Enhancing pre-intermediate EFL learners' reading. Cogent Arts \& Humanities. vol. 7, no. 1738833, pp. 1-15.

[4] Nezami, S. R. A. 2012. A Critical Study of Comprehension Strategies and General Problems in Reading Skill Faced by Arab EFL Learners with Special Reference to Najran University in Saudi Arabia. International J. Soc. Sci. \& Education. vol. 2, no. 3, pp. 306-316.

[5] Ahsanah, F. 2015. Group Investigation: A cooperative Learning Method for the 10th Grade Students in Speaking English Classroom. TELL Journal. vol. 3, no. 1, pp. 57-69.

[6] Slavin, R., Sharan, S., Kagan, S., Hertz-Lazarowitz, R., Webb, C., and Schmuck, R. 1985. Learning to Cooperate, Cooperating to Learn. New York: Plenum Press.

[7] Karafkan, M. A., and Aghazadeh, Z. 2015. Investigating the Effects of Group Investigation (GI) and Cooperative Integrated Reading and Comprehension (CIRC) as the Cooperative Learning Techniques on Learner's Reading Comprehension. International Journal of Applied Linguistics \& English Literature. vol. 4, no. 6, pp. 8-15,

[8] Jalilifar, A. 2010. The effect of cooperative learning techniques on college students' reading comprehension. Elsevier. vol. 38, no. 1, pp. 96-108.

[9] Chotimah, N., and Rukmini, D. 2017. The Effectiveness of Students Team Achievement Division (STAD) and Group Investigation (GI) Technique to Teach Reading Comprehension to Students with High and Low Motivation. English Education Journal. vol. 7, no. 1, pp. 47-53,

[10] Tan, I. G. C., Sharan, S., and Lee, C. K. Eng. 2010. Group Investigation Effects on Achievement, Motivation, and Perceptions of Students in Singapore. The Journal of Educational Research. vol. 100, no. 3, pp. 142-154.

[11] Untoro, B. 2016.The Effect of Group Investigation and Learning Style on Students' Writing of Analytical Exposition. IJEE (Indonesian Journal of English Education. vol. 3, no. 1, pp. 29-45.

[12] Arsy, H. I., Prasetyo, A. P. B., and Subali, B. 2020. Predict-Observe-Explain Strategy with Group Investigation Effect on Students' Critical Thinking Skills and Learning Achievement. Journal of Primary Education. vol. 9, no. 1, pp. 75-83.

[13] Parinduri, S. H., Sirait, M., and Sani, R. A. 2017. The Effect of Cooperative Learning Model Type Group Investigation for Student's Conceptual Knowledge and Science Process Skills. IOSR Journal of Research \& Method in Education (IOSR-JRME). vol. 7, no. 4, pp. 49-54.

[14] Samuel and Ruth, I. 2018. Effects of Jigsaw IV, Group Investigation and Reversed Jigsaw Cooperative Instructional Strategies on Basic Science Students' Achievement and Retention. International Journal of Innovative Education Research. vol. 6, no. 2, pp. 54-62.

[15] WL, M. Y., Hidayat, N., \& Susanto, D. A. 2019. A Qualitative Study Of EFL English Teacher's Perceptions Towards Teaching Vocabulary Using Word Games For Junior High Schools In 
Semarang Central Java: To Use Or To Reject?. Advances in Social Science, Education and Humanities Research. vol. 287, pp. 170-175, 2018.

[16] Vattøy, K. D., \& Smith, K. 2019. Students' perceptions of teachers' feedback practice in teaching English as a foreign language. Teaching and Teacher Education. 85, 260-268.

[17] Avello, M., Camacho-Miñano, M. d.-M. Grande, E. U. and Campo, C. d. 2019. Do You Use English in Your Daily Life?" Undergraduate Students' Perceptions of Their Extramural Use of English. Journal of Teaching in International Business. vol. 30, no. 1, pp. 77-94.

[18] Akbari, Z. 2016. The Study of EFL Students' Perceptions of Their Problems, Needs and Concerns over Learning English: The Case of MA Paramedical Students. Elsevier. vol. 232, no. 1, pp. 24-34.

[19] Grabe, W. 2009. Reading in a Second Language, Moving From Theory to Practice. New York: Cambridge University Press.

[20] Marzban, A. and Alinejad, F. 2014. The Effect of Cooperative Learning on Reading Comprehension of Iranian EFL Learners. Elsevier. vol. 116, no. 1, pp. 3744-3748,

[21] Marcos, R. I. S., Ferández, V. L., González, M. T. D., and Silver, J. P. 2020. Promoting children's creative thinking through reading and writing in a cooperative learning classroom. Elsevier. vol. 36, no. 100663, pp. 1-13.

[22] Parveen, Q., Yousuf, M. I., and Mustafa, S. 2017. An experimental study on the effect of cooperative learning on students' academic achievement and students' perceptions towards cooperative Learning. Anthropologist, vol. 27, no. 3, pp. 69-76. 